\title{
Microwave-assisted kinetic resolution of homochiral diols using lipase
}

\author{
Hervé Rouillard ${ }^{1}$, Emmanuel Deau ${ }^{1}$, Lisianne Domon ${ }^{1}$, Jean-René Chérouvrier ${ }^{1}$, Marianne \\ Graber $^{1}$ and Valérie Thiéry ${ }^{1, *}$ \\ Université de La Rochelle, UMR CNRS 7266 LIENSs, Avenue Crépeau, 17042 La Rochelle, France; \\ E-Mail: herve.rouillard@univ-lr.fr; emmanuel.deau@univ-lr.fr; lisianne.domon@univ-lr.fr; \\ jcherouv@univ-lr.fr; marianne.graber@univ-lr.fr; valerie.thiery@univ-lr.fr
}

* Author to whom correspondence should be addressed; E-Mail: valerie.thiery@univ-lr.fr; Tel.: +33-5-46-45-82-76; Fax: +33-5-46-45-82-65.

\begin{abstract}
Since last decade, biocatalysts have become an attractive alternative to conventional chemical methods, especially for organic synthesis, due to their great properties. Among these enzymes, lipases are the most widely used, because they are cheap, easily available, cofactor free and have broad substrate specificity. Combined to microwave irradiation in non-aqueous medium, the published results suggest that microwave irradiation can have an influence on enzyme stability and activity, in addition to altering/enhancing reaction rates and/or enantioselectivities, called nonthermal microwave effects. However, the role of the microwave irradiation on enzyme still reminds controversial. This presentation will deal with the benefits of the use of lipases and the microwave irradiation. To have a better understanding of the system, different parameters were studied and analyzed, such as the impact of the microwave power, the temperature. The optimization of the reaction parameters will lead to the obtainment of useful chiral homochiral diols in clean, efficient and safe way.
\end{abstract}

Keywords: biocatalysis; microwave irradiation; lipase; homochiral diols; resolution

\section{Introduction}

Enantiomerically pure vicinal diols are versatile chemical intermediates for the production of flavors and fragances. As part of our work concerning the synthesis of enantioselective synthesis of methyl jasmonate derivatives from optically active bicycle[3.3.0]octane derivatives by transannular reaction, we needed first to prepare enantiopure homochiral $(1 R, 2 R)$ and $(1 S, 2 S)$ 5-cyclooctene-1,2-diols. In recent years, the employment of biocatalysts for organic synthesis has become an attractive alternative to conventional chemical methods. Lipases are the most widely used because they are inexpensive, easily available, cofactor free and have broad substrate specificity. ${ }^{1}$ We decided to turn our interest to microwave-assisted lipase mediated kinetic resolution involving CaLB (lipase B from Candida antartica) or PS (Pseudomonas cepacia)-catalyzed acetylation of diol. The use of microwave irradiation in biocatalysis can enhance the enzyme activity: for example in resolution reaction, in specific oxido-reduction reaction or in hydrolysis. Combined to microwave irradiation in non-aqueous medium, the published results suggest that microwave irradiation can have also an influence on enzyme stability and activity, in addition to altering/enhancing reaction rates and/or enantioselectivities, called nonthermal microwave effects. ${ }^{2}$ However, the role of the microwave irradiation on enzyme still reminds controversial. ${ }^{3}$ We herein report our studies on microwave-assisted 
lipase resolution of diol. To have a better understanding of the system, different parameters were studied and analyzed, such as the impact of the microwave power or the temperature.

\section{Methods/Experimental section}

Lipases from Pseudomonas cepacia (immobilized on diatome MKBB3465, $500 \mathrm{PLU}^{-1}$ ) and Candida antarctica (immobilized on acrylic resin 077K1155, $10000 \mathrm{PLU}^{-1}$ Novozym $435^{\circledR}$ or free form) were purchased from Sigma Aldrich. The entire commercials available were purchased from Sigma Aldrich.

IR spectra were recorded on a Perkin-Elmer Spectrum 100 IRFT-ATR instrument. ${ }^{1} \mathrm{H}$ and ${ }^{13} \mathrm{C}$ NMR were recorded on a JEOL JNM LA400 (400 MHz) spectrometer. Chemical shifts $(\delta)$ are reported in parts per million (ppm) downfield from tetramethylsilane (TMS) which was used as internal standard. Coupling constants $\mathrm{J}$ are given in Hz. The high resolution mass spectra (HRMS) were recorded on a Varian MAT311 spectrometer in the Centre Régional de Mesures Physiques de l'Ouest (CRMPO), Université de Rennes. Analytical thin layer chromatography (TLC) was performed on Merck Kieselgel 60 F254 aluminum packed plates.

Enantiomeric excesses were calculated by gas chromatography (Agilent 7890A) equipped with an autosampler (7688B) and flame ionization detector (FID) for the products detection. For the experiment, a CP-Chirasil-Dex $(0.25 \mathrm{~mm} \times 25 \mathrm{~m}$ x $0.25 \mu \mathrm{m}$, Cromopack $)$ column was used. The injector and the detector were kept at $180{ }^{\circ} \mathrm{C}$. Nitrogen was used as gas carrier at a flow of $1.5 \mathrm{~mL} / \mathrm{min}$. Hydrogen, air and nitrogen were supplied to the FID at $35 \mathrm{~mL} \cdot \mathrm{min}^{-1}, 350 \mathrm{~mL} \cdot \mathrm{min}^{-1}$ and $25 \mathrm{~mL} \cdot \mathrm{min}^{-1}$ respectively. The products are analyzed at $110^{\circ} \mathrm{C}$.

High performance liquid chromatography (HPLC) was carried out in a Watters 600s combined with an autosampler (Watters 717 plus). The Chiralpak-AD column (Amylose tris-(3,5dimethylphenylcarbamate) coated on $10 \mu \mathrm{m}$ silica-gel, Daicel Chemical, 250 x $4.6 \mathrm{~mm}$ ) in a flowrate (n-Heptane/EtOH, 9/1) of $1 \mathrm{~mL} \cdot \mathrm{min}^{-1}$ is used. Products are analyzed by a differential refractometer (Watters 410)

Optical rotation was measured on a Perkin Elmer 341 polarimeter.

Microwave reactions were conducted using a CEM Discover ${ }^{\circledR}$, mode operating systems working at $2.45 \mathrm{GHz}$, with a power programmable from 1 to 300W. The microwave can be equipped with a Cool mate $^{\circledR}$ system allowing reactions at high irradiation (up to $300 \mathrm{~W}$ ). This system is cooled by a cryogenic fluid (Galden HT-55 ${ }^{\circledR}$ ).

In closed vessel mode, microwave irradiation experiments were carried out using a single-mode microwave instrument (Initiator, Biotage) working at $2.45 \mathrm{GHz}$, with a power programmable from 1 to $450 \mathrm{~W}$ (0-20 bars).

\section{(Z)-(1S,8R)-9-oxa-bicyclo[6.1.0]non-4-en (1)}

Under inert atmosphere, to a solution of cyclo-octa-1,5-dien $(20 \mathrm{~g}, 0.161 \mathrm{~mol})$ and sodium carbonate $(117.6 \mathrm{~g}, 1.11 \mathrm{~mol})$ in dichloromethane $(560 \mathrm{~mL})$ stirred at $0^{\circ} \mathrm{C}$ is added dropwise a solution of peracetic acid $(42.7 \mathrm{~mL}, 0.222 \mathrm{~mol})$ in dichloromethane $(500 \mathrm{~mL})$ during 2 hours. The mixture was stirred during 8 hours at $0^{\circ} \mathrm{C}$ and 12 hours at room temperature. The mixture was washed with $500 \mathrm{~mL}$ of water and extracted with $(3 \times 250 \mathrm{~mL})$ of dichloromethane. The organic layers were dried with magnesium sulfate anhydrous and concentrated under reduced pressure. 
The crude residue was purified by chromatography column (silica gel, petroleum ether/ethyl acetate 90/10) to provide the (Z)-(1S,8R)-9-oxa-bicyclo[6.1.0]non-4-en $\mathbf{1}(5.697 \mathrm{~g}, 67 \%$ yield) as a colorless oil; $v_{\max }\left(\mathrm{cm}^{-1}\right)$ : 3003, 2906, 2887, 1655, 1445, 1428, 1228, 1669, 1099, 1039, 934, 762, 743; $\delta_{\mathrm{H}}\left(400 \mathrm{MHz}, \mathrm{CDCl}_{3}\right)$ 5,56-5.60 (2H, m, $\left.\mathrm{C} \underline{H}=\mathrm{C} \underline{\mathrm{H}}\right), 3.00-3.02(2 \mathrm{H}, \mathrm{m}, \mathrm{C} \underline{\mathrm{HC}} \underline{\mathrm{H}}), 2.41-2.47(2 \mathrm{H}, \mathrm{m}$, $\left.\mathrm{C}_{2}\right)$, 2.08-2.15 (2H, m, $\left.\underline{\mathrm{C}}_{2}\right), 1.98-2.17\left(4 \mathrm{H}, \mathrm{m}, 2 \mathrm{xC}_{2}\right) ; \delta_{\mathrm{C}}\left(100 \mathrm{MHz}, \mathrm{CDCl}_{3}\right) 128.6,56.2,27.8$, 23.4.

\section{(Z)-cyclooct-5-en-1,2-diol (2)}

Under inert atmosphere, to the (Z)-(1S,8R)-9-oxa-bicyclo[6.1.0]non-4-en (1) (5.697 g, $45.9 \mathrm{mmol})$ vigorously stirred is added a solution of sulfuric acid $2 \mathrm{M}(25.3 \mathrm{~mL}, 50.47 \mathrm{mmol})$. After 4 hours under stirring, the mixture is extracted with $3 \times 75 \mathrm{~mL}$ of ethyl acetate. The organic layers were washed with a saturated solution of sodium hydrogenocarbonate $(40 \mathrm{~mL})$, brine $(40 \mathrm{~mL})$, dried with magnesium sulfate and concentrated under vacuum. The crude residue was purified by chromatography column (silica gel, petroleum ether/ethyl acetate 60/40) to give the rac-(Z)-cyclooct-5-en-1,2-diol 2 (3.691 g, $57 \%$ yield) as a colorless oil; $v_{\max }\left(\mathrm{cm}^{-1}\right): 3362,3014,2964,2861,1651,1427,1429,1400,1271$, $1202,1010,994,976,947,868,732,719 ; \delta_{\mathrm{H}}\left(400 \mathrm{MHz}, \mathrm{CDCl}_{3}\right): 5.55-5.59(2 \mathrm{H}, \mathrm{m}, \mathrm{C} \underline{\mathrm{H}}=\mathrm{C} \underline{\mathrm{H}}), 3.57-$ $3.61(4 \mathrm{H}, \mathrm{m}, \mathrm{C} \underline{\mathrm{HO}} \underline{\mathrm{HC}} \underline{\mathrm{HO}} \underline{\mathrm{H}}), 2.29-2.35\left(2 \mathrm{H}, \mathrm{m}, \underline{\mathrm{C}}_{2}\right), 2.00-2.12\left(4 \mathrm{H}, \mathrm{m}, 2 \times \underline{\mathrm{H}}_{2}\right), 1.52-1.58(2 \mathrm{H}, \mathrm{m}$, $\left.\mathrm{C}_{2}\right) ; \delta_{\mathrm{C}}\left(100 \mathrm{MHz}, \mathrm{CDCl}_{3}\right): 128.9,73.8,33.1,22.6$; HRMS: calculated for $\mathrm{C}_{8} \mathrm{H}_{14} \mathrm{O}_{2}[\mathrm{M}]^{+}: 142.09938$, Found : 142.1001 (5 ppm).

\section{(1R,2R)-(Z)-1-hydroxy-cyclooct-4-enyle acetate (3a)}

Compound 3a is obtained as a colorless oil $[\alpha]_{\mathrm{D}}{ }^{20}-3.0^{\circ}\left(c 1.00 \mathrm{CHCl}_{3}\right) \cdot v_{\max }\left(\mathrm{cm}^{-1}\right): 3449,3012$, 2936, 1717, 1654, 1430, 1235, 1030, 971, 933, 720; $\delta_{\mathrm{H}} \mathrm{NMR}\left(400 \mathrm{MHz}, \mathrm{CDCl}_{3}\right): 5.59-5.69(2 \mathrm{H}, \mathrm{m}$, $\mathrm{C} \underline{\mathrm{H}}=\mathrm{C} \underline{\mathrm{H}}), 4.95(1 \mathrm{H} \mathrm{dt}, J=8.8 \mathrm{~Hz}, 4.0 \mathrm{~Hz}, \mathrm{C} \underline{\mathrm{HOAc}}), 3.90(1 \mathrm{H}, \mathrm{dt}, J=2.1 \mathrm{~Hz}, \mathrm{C} \underline{\mathrm{HOH}}), 2.54(1 \mathrm{H}, \mathrm{s}, \mathrm{OH})$,

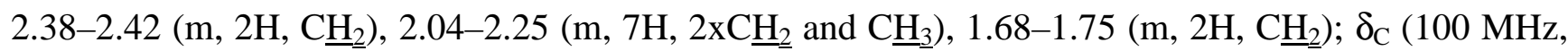
$\left.\mathrm{CDCl}_{3}\right):$ 170.9, 129.6, 128.6, 77.3, 72.1, 32.8, 30.0, 22.8, 22.8, 21.2. GC: Cromopack column $\mathrm{t}_{\mathrm{R}}=59.7$ min HRMS: calcd for $\mathrm{C}_{8} \mathrm{H}_{14} \mathrm{O}_{2}\left[\mathrm{M}-\mathrm{CH}_{2} \mathrm{CO}\right]^{+}: 142.09938$, Found : 142.0993 (0 ppm).

\section{(1S,2S)-(Z)-1-hydroxy-cyclooct-4-enyle acetate (3b)}

Compound $3 \mathbf{b}$ is obtained as a colorless oil. $[\alpha]_{\mathrm{D}}{ }^{20}+3.2^{\circ}\left(c 1.00 \mathrm{CHCl}_{3}\right) \cdot v_{\max }\left(\mathrm{cm}^{-1}\right): 3449,3012$, 2936, 1717, 1654, 1430, 1235, 1030, 971, 933, 720; $\delta_{\mathrm{H}} \mathrm{NMR}\left(400 \mathrm{MHz}, \mathrm{CDCl}_{3}\right): 5.59-5.69(2 \mathrm{H}, \mathrm{m}$, $\mathrm{C} \underline{\mathrm{H}}=\mathrm{C} \underline{\mathrm{H}}), 4.95(1 \mathrm{H} \mathrm{dt}, J=8.8 \mathrm{~Hz}, 4.0 \mathrm{~Hz}, \mathrm{C} \underline{\mathrm{HOAc}}), 3.90(1 \mathrm{H}, \mathrm{dt}, J=2.1 \mathrm{~Hz}, \mathrm{C} \underline{\mathrm{HOH}}), 2.54(1 \mathrm{H}, \mathrm{s}, \mathrm{O} \underline{\mathrm{H}})$, 2.38-2.42 (m, $\left.2 \mathrm{H}, \underline{\mathrm{CH}}_{2}\right), 2.04-2.25\left(\mathrm{~m}, 7 \mathrm{H}, 2 \underline{\mathrm{CH}}_{2}\right.$ and $\left.\underline{\mathrm{CH}}_{3}\right), 1.68-1.75\left(\mathrm{~m}, 2 \mathrm{H}, \underline{\mathrm{C}}_{2}\right)$; $\delta_{\mathrm{C}}(100 \mathrm{MHz}$, $\left.\mathrm{CDCl}_{3}\right):$ 170.9, 129.6, 128.6, 77.3, 72.1, 32.8, 30.0, 22.8, 22.8, 21.2. GC: Cromopack column $\mathrm{t}_{\mathrm{R}}=56.6$ min HRMS: calcd for $\mathrm{C}_{8} \mathrm{H}_{14} \mathrm{O}_{2}\left[\mathrm{M}-\mathrm{CH}_{2} \mathrm{CO}\right]^{+}:$142.09938, Found : 142.0993 (0 ppm).

\section{$(1 R, 2 R)-(Z)-2$-acetoxy-cyclooct-4-enyle acetate $(\mathbf{4 a})$}

Compound $4 \mathbf{a}$ is obtained as a colorless oil. $[\alpha]_{\mathrm{D}}^{20}+81.0^{\circ}\left(c 1.00 \mathrm{CHCl}_{3}\right) \cdot v_{\max }\left(\mathrm{cm}^{-1}\right): 3016,2938$, $2866,1732,1654,1431,1370,1226,1244,1032,978,946,735,722 ; \delta_{\mathrm{H}}\left(400 \mathrm{MHz}, \mathrm{CDCl}_{3}\right): 5.69-$ $5.62(2 \mathrm{H}, \mathrm{m}, \mathrm{C} \underline{\mathrm{H}}=\mathrm{C} \underline{\mathrm{H}}), 5.05-5.08(2 \mathrm{H}, \mathrm{m}, 2 \mathrm{xC} \underline{\mathrm{HOH}}), 2.35-2.41\left(2 \mathrm{H}, \mathrm{m}, \mathrm{C}_{2}\right), 2.12-2.18(2 \mathrm{H}, \mathrm{m}$, $\left.\mathrm{C}_{2}\right), 2.01-2.04\left(2 \mathrm{H}, \mathrm{m}, \mathrm{C}_{2} \underline{H}_{2}\right), 1.96\left(\mathrm{~s}, 6 \mathrm{H}, 2 \mathrm{C}_{\underline{3}}\right), 1.73-1.76\left(2 \mathrm{H}, \mathrm{m}, \mathrm{C}_{2}\right)$ ). $\delta_{\mathrm{C}}\left(100 \mathrm{MHz}, \mathrm{CDCl}_{3}\right)$ :

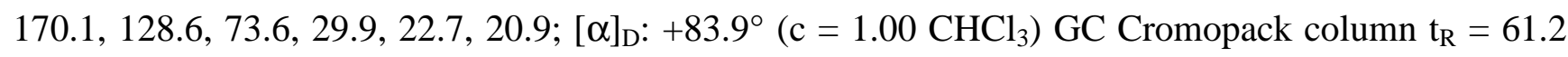
$\min$ 
(1S,2S)-(Z)-2-acetoxy-cyclooct-4-enyle acetate $(\mathbf{4 b})$

Compound $4 \mathbf{b}$ is obtained as a colorless oil; $[\alpha]_{\mathrm{D}}:-79.0^{\circ}\left(c 1.00 \mathrm{CHCl}_{3}\right) \cdot v_{\max }\left(\mathrm{cm}^{-1}\right): 3016,2938$, $2866,1732,1654,1431,1370,1226,1244,1032,978,946,735,722 ; \delta_{\mathrm{H}}\left(400 \mathrm{MHz}, \mathrm{CDCl}_{3}\right): 5.69-$ $5.62(2 \mathrm{H}, \mathrm{m}, \mathrm{C} \underline{\mathrm{H}}=\mathrm{C} \underline{\mathrm{H}}), 5.05-5.08(2 \mathrm{H}, \mathrm{m}, 2 \mathrm{xC} \underline{\mathrm{HOH}}), 2.35-2.41\left(2 \mathrm{H}, \mathrm{m}, \mathrm{C}_{2}\right), 2.12-2.18(2 \mathrm{H}, \mathrm{m}$,

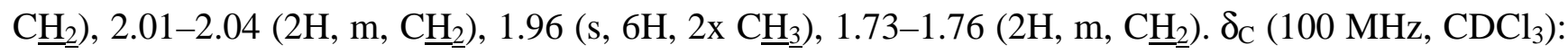
170.1, 128.6, 73.6, 29.9, 22.7, 20.9; GC: Cromopack column $\mathrm{t}_{\mathrm{R}}=59.4 \mathrm{~min}$; HRMS calcd for $\mathrm{C}_{10} \mathrm{H}_{16} \mathrm{O}_{3}$ $\left[{\mathrm{M}-\mathrm{CH}_{2} \mathrm{CO}}^{+}: 184.10994\right.$, Found : 184.1091 (4 ppm).

General procedure for enantioselective acetylation of racemic (Z)-cyclooct-5-en-1,2-diol (2) using lipase

Under inert atmosphere, to a solution of racemic diol $2(0.2 \mathrm{~g}, 1.41 \mathrm{mmol})$ solubilized in $2.5 \mathrm{~mL}$ of THF were added the vinyl acetate $(1.3 \mathrm{~mL}, 14 \mathrm{mmol})$ and the appropriated immobilized lipase (50 $\mathrm{mg}$ ). The mixture was stirred at various temperature under classical heating or microwave irradiation (see Table 1, Table 2, Table3). The mixture was filtrated, extracted with ethyl acetate $(3 \mathrm{x} 7 \mathrm{~mL})$. The organic layers were washed with $3 \mathrm{~mL}$ of $\mathrm{HCl} 5 \%, 3 \mathrm{~mL}$ of sodium hydrogenocarbonate, brine, dried with magnesium sulfate and concentrated under reduced pressure. The crude residue was purified by chromatography column (silica gel, petroleum ether/ethyl acetate 60/40) to give the $(1 R, 2 R)-(\mathrm{Z})-1$ hydroxy-cyclooct-4-enyle acetate $\mathbf{3 a}, \mathbf{3 b}, \mathbf{4 b}$.

\section{General procedure for the hydrolysis of (Z)-2-acetoxy-cyclooct-4-enyle acetate (4) by Candida antarctica lipase $B$}

Under inert atmosphere, to a solution of racemic (Z)-2-acetoxy-cyclooct-4-enyle acetate 4 ( $0.2 \mathrm{~g}$, $0.88 \mathrm{mmol}$ ) in $2.5 \mathrm{~mL}$ of phosphate buffer $0.1 \mathrm{M}, \mathrm{pH}=7.0$, was added the lipase $(50 \mathrm{mg})$. The mixture was stirred at $50^{\circ} \mathrm{C}$ under microwave irradiation (see Table 4, Table 5, Table 6). The mixture was filtrated, extracted with ethyl acetate $(3 \times 7 \mathrm{~mL})$. The organic layers were washed with $3 \mathrm{~mL}$ of $\mathrm{HCl} 5 \%$, $3 \mathrm{~mL}$ of sodium hydrogenocarbonate, brine, dried with magnesium sulfate and concentrated under reduced pressure. The crude residue was purified by chromatography column (silica gel, petroleum ether/ethyl acetate 60/40) to give $\mathbf{3 a}, \mathbf{3 b}$ and $\mathbf{4 a}, \mathbf{4 b}$.

\section{Diacetate enrichment}

The (Z)-2-acetoxy-cyclooct-4-enyle $4 \mathbf{a}$ obtained in section 1.10 .2 is solubilized in $2.5 \mathrm{~mL}$ of phosphate buffer $0.1 \mathrm{M}, \mathrm{pH}=7.0$. The Candida antarctica lipase $\mathrm{B}(50 \mathrm{mg})$ is added and the mixture is stirred at $50^{\circ} \mathrm{C}$ during 14 hours by microwave irradiation (open vessel). The mixture was filtrated, extracted with ethyl acetate $(3 \times 7 \mathrm{~mL})$, The organic layers were washed with $3 \mathrm{~mL}$ of $\mathrm{HCl} 5 \%, 3 \mathrm{~mL}$ of sodium hydrogenocarbonate, brine, dried with magnesium sulfate and concentrated under reduced pressure. The crude residue was purified by chromatography column (silica gel, petroleum ether/ethyl acetate 60/40) to give the (Z)-(1S,2S)-2-hydroxy-cyclooct-4-enyle $\mathbf{3 b}$ acetate in $49 \%$ overall yield $(0.098 \mathrm{~g}$, ee $>99 \%)$ and $\mathbf{4 a}$ in $51 \%$ overall yield $(0.083 \mathrm{~g}$, ee $>99 \%)$. 
The cryogenic fluid (Garlon $80^{\circledR}$ ) of Cool mate ${ }^{\circledR}$ is cooled by dry ice, and maintained at $7^{\circ} \mathrm{C}$. To a solution of racemic diol $2(0.2 \mathrm{~g}, 1.406 \mathrm{mmol})$ solubilized in $2.5 \mathrm{~mL}$ of THF is added the vinyl acetate $(1.3 \mathrm{~mL}, 14 \mathrm{mmol})$ and the Candida antarctica lipase $(50 \mathrm{mg})$. The mixture is irradiated with an intern temperature set at $35^{\circ} \mathrm{C}$, leading to an irradiation power of $300 \mathrm{~W}$. After 7 hours of irradiation, the mixture was filtrated, extracted with ethyl acetate $(3 \times 7 \mathrm{~mL})$. The organic layers were washed with 3 $\mathrm{mL}$ of $\mathrm{HCl} 5 \%, 3 \mathrm{~mL}$ of sodium hydrogenocarbonate, brine, dried with magnesium sulfate and concentrated under reduced pressure. The crude residue was purified by chromatography column (silica gel, petroleum ether/ethyl acetate 60/40) to give the (Z)-(1R,2R)-1-hydroxy-cyclooct-4-enyle acetate $\mathbf{3 a}$ in $42 \%$ yield $(0.108 \mathrm{~g}$, ee=67\%), (Z) $(1 S, 2 S)$-2-acetoxy-cyclooct-4-enyle acetate $\mathbf{4 b}$ in $2 \%$ yield $(e e=99 \%)$ and $(Z)-$ cyclooct-5-en-1,2-diol in $51 \%$ yield $(0.102 \mathrm{~g}$, ee=50\%).

\section{Synthesis of diols by saponification of esters}

Under inert atmosphere, to a solution of enantiopure $(\mathrm{Z})-(1 R, 2 R)$-2-acetoxy-cyclooct-4-enyle acetate 4a $(0.2 \mathrm{~g}, 17.3 \mathrm{mmol})$ or enantiopure monoacetate $\mathbf{3 b}(0.2 \mathrm{~g}, 12.0 \mathrm{mmol})$ in methanol $(10 \mathrm{~mL})$ was added potassium carbonate anhydrous ( $4 \mathrm{mg}, 0.86$. mmol). The mixture was stirred 8 hours at $0^{\circ} \mathrm{C}$, and $10 \mathrm{~mL}$ of hydrochloric acid $1 \mathrm{M}$ are added. The aqueous layer is extracted with ethyl acetate $(3 \times 8 \mathrm{~mL})$, washed with a saturated solution of sodium hydrogenocarbonate $(5 \mathrm{~mL})$ and brine $(5 \mathrm{~mL})$. The organic layers were dried with magnesium sulfate, concentrated under reduced pressure.

\section{(1R,2R)-(Z)-Cyclooct-5-en-1,2-diol (2a)}

The crude residue was purified by chromatography column (silica gel, petroleum ether/ethyl acetate $60 / 40)$ to give the $(\mathrm{Z})-(1 R, 2 R)$-cyclooct-5-en-1,2-diol $\mathbf{2 a}(0.152 \mathrm{~g}, 99 \%$ yield $)$ as a white solid; $[\alpha]_{\mathrm{D}}{ }^{20}$ $20,9^{\circ}\left(c 1,00 \mathrm{CHCl}_{3}\right) ; v_{\max }\left(\mathrm{cm}^{-1}\right): 3362,3014,2964,2861,1651,1427,1429,1400,1271,1202,1010$, 994, 976, 947, 868, 732, 719; $\delta_{\mathrm{H}}\left(400 \mathrm{MHz} \mathrm{CDCl}_{3}\right): 5.55-5.59(2 \mathrm{H}, \mathrm{m}, \mathrm{C} \underline{\mathrm{H}}=\mathrm{C} \underline{\mathrm{H}}), 3.57-3.61(\mathrm{~m}, 4 \mathrm{H}$, $2 \mathrm{xC} \underline{\mathrm{HOH}}), 2.29-2.35\left(2 \mathrm{H}, \mathrm{m}, \mathrm{C}_{2}\right), 2.00-2.12\left(2 \mathrm{H}, \mathrm{m}, \mathrm{C}_{2}\right), 1.52-1.58\left(2 \mathrm{H}, \mathrm{m}, \mathrm{C}_{2}\right) ; \delta_{\mathrm{c}}(100 \mathrm{MHz}$, $\mathrm{CDCl}_{3}$ ): 128.9, 73.8, 33.1, 22.6; HRMS: calculated for $\mathrm{C}_{8} \mathrm{H}_{14} \mathrm{O}_{2}[\mathrm{M}]^{+}:$142.09938, Found : 142.1001 (5 $\mathrm{ppm}) . \mathrm{HPLC} \mathrm{t}_{\mathrm{R}}=11.9 \mathrm{~min}$

\section{(1S,2S)-(Z)- Cyclooct-5-ène-1,2-diol (2b)}

The crude residue was purified by chromatography column (silica gel, petroleum ether/ethyl acetate 60/40) to give the $(\mathrm{Z})-(1 S, 2 S)$-cyclooct-5-en-1,2-diol $\mathbf{2 b}(0.153 \mathrm{~g}, 99 \%$ yield $)$ as a white solid. $[\alpha]_{\mathrm{D}}$ : $+18.2^{\circ}\left(\mathrm{c}=1,00 \mathrm{CHCl}_{3}\right) \nu_{\max }\left(\mathrm{cm}^{-1}\right): 3362,3014,2964,2861,1651,1427,1429,1400,1271,1202$, $1010,994,976,947,868,732,719 ; \delta_{\mathrm{H}}\left(400 \mathrm{MHz}, \mathrm{CDCl}_{3}\right): 5.55-5.59(2 \mathrm{H}, \mathrm{m}, \mathrm{C} \underline{\mathrm{H}}=\mathrm{C} \underline{\mathrm{H}}), 3.57-3.61(\mathrm{~m}$, $4 \mathrm{H}, 2 \mathrm{xC} \underline{\mathrm{HOH}}), 2.29-2.35\left(2 \mathrm{H}, \mathrm{m}, \mathrm{C}_{2}\right), 2.00-2.12\left(2 \mathrm{H}, \mathrm{m}, \mathrm{C}_{2}\right), 1.52-1.58\left(2 \mathrm{H}, \mathrm{m}, \mathrm{C}_{2}\right) ; \delta_{\mathrm{c}}(100$ $\mathrm{MHz}, \mathrm{CDCl}_{3}$ ): 128.9, 73.8, 33.1, 22.6; HRMS: calculated for $\mathrm{C}_{8} \mathrm{H}_{14} \mathrm{O}_{2}[\mathrm{M}]^{+}:$142.09938, Found : $142.1001(5 \mathrm{ppm})$. HPLC $\mathrm{t}_{\mathrm{R}}=10.8 \mathrm{~min}$. 


\section{Results and Discussion}

In the context of the growing general interest for reducing energy costs, heating chemical reactions under microwave irradiation is a useful approach for achieving higher reaction kinetics and the formation of cleaner products. ${ }^{4}$

Rac-diol (2) and rac-diacetate (4) were prepared from cycloocta-1,5-diene by a three-steps sequence including epoxidation, ring opening with aqueous sulfuric acid followed by acetylation with acetic anhydride.

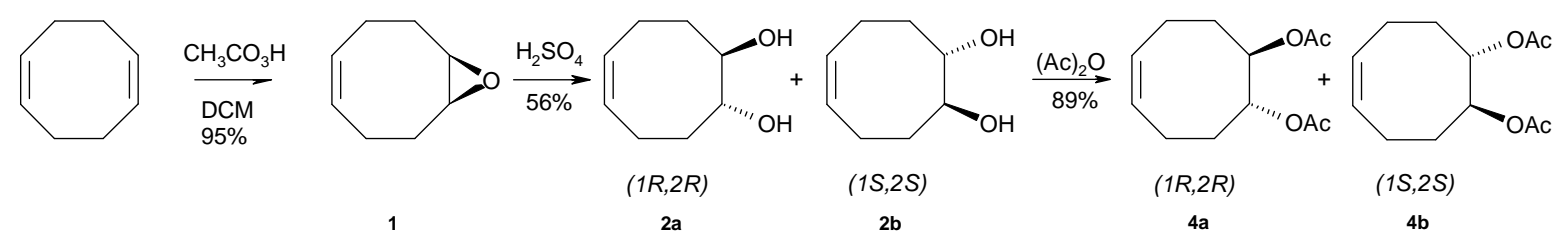

Epoxidation and hydrolysis of cyclo-octa-1,5-dien leading to diols 2 and diacetate 4

The preparation of optically active 5-cyclooctene-1,2-diol 2 was first envisaged by using microwaveassisted lipase-catalyzed desymmetrization of meso-symmetric diol $\mathbf{2}$ using vinyl acetate as the acylating agent in THF as solvent among isooctane, M2B2. In order to perform the reaction under microwave irradiation, we decided to choose thermostable immobilized lipases that could to be used under microwave irradiation: Novozyme 435® (CaLB immobilized on acrylic resin) and PS-D (Pseudomonas cepacia immobilized on diatomite). In the literature by enzyme immobilization, enhanced enzyme activity, selectivity, stability, and reusability in organic media may be achieved compared to the native enzyme. It must be noted that Deau previously showed that the resolution of rac-diol 2 using free Pseudomonas cepacia at $55^{\circ} \mathrm{C}$ in THF during 7 days afforded with a good conversion rac-monoacetate $3(47 \%, 0 \%$ ee) and rac-diol $2(51 \%, 0 \%$ ee) but with no selectivity at all.

Performed at $35^{\circ} \mathrm{C}$ under conventional heating CaLB-enzymatic acylation of rac-diol (2) afforded after 3 weeks $28 \%$ of $(1 R, 2 R)$-monoacetate $3 \mathbf{a}(42 \%$ ee) and $6 \%$ of $(1 S, 2 S)$-diacetate $4 \mathbf{b}$ with an excellent $99 \%$ ee. A higher temperature $\left(50^{\circ} \mathrm{C}\right)$ led after 7 days to modest yields of monoacetate $3 \mathbf{a}$ and diacetate $\mathbf{4 b}$ but with a real enhancement of ee ( $20 \%$ with ee $>99 \%)$.

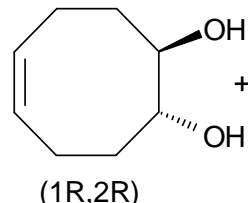

$2 a$

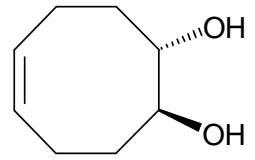

$(1 \mathrm{~S}, 2 \mathrm{~S})$

$2 \mathrm{~b}$

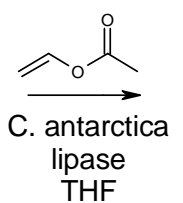
THF

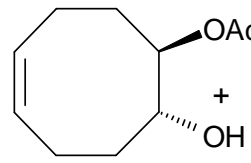

$(1 \mathrm{R}, 2 \mathrm{R})$

3a

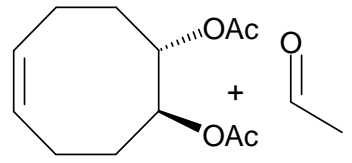

(1S,2S)

$4 b$

\begin{tabular}{ccccccc}
\hline $\begin{array}{c}\text { Mode of } \\
\text { heating }\end{array}$ & $\begin{array}{c}\text { Temperature } \\
\left({ }^{\circ} \mathrm{C}\right)\end{array}$ & Time & $\begin{array}{c}\text { Monoacetate 3a } \\
\text { yield }(\%)\end{array}$ & ee (\%) & $\begin{array}{c}\text { Diacetate } \mathbf{4 b} \\
\text { yield }(\%)\end{array}$ & ee (\%) \\
\hline Classical & 35 & 3 weeks & 28 & 42 & 6 & $>99$ \\
Classical & 50 & 7 days & 30 & 50 & 20 & $>99$ \\
Classical & 50 & 14 hours & traces & & - & \\
\hline
\end{tabular}

Table 1 : Enantioselective acetylation of diol (2) using CaLB lipase by classical heating 
Under microwave irradiation at $35^{\circ} \mathrm{C}(5 \mathrm{~W})$, racemic diol 2 proceeded to $(1 R, 2 R)$-monoacetate 3a $(32 \%, 45 \%$ ee), trace of $(1 S, 2 S)$-diacetate $\mathbf{4 b}(5 \%,>99 \%$ ee) and $65 \%$ of diol $\mathbf{2}(23 \%$ ee). In order to study the influence of the irradiation power on the biocatalytic media, we decided to apply maximum of power $(300 \mathrm{~W})$ in maintaining the temperature at $35^{\circ} \mathrm{C}$ by using a microwave oven combined with a Cool mate ${ }^{\circledR}$. We noticed an enhancement of the yield and the enantiomeric ratio of $(1 R, 2 R)$ monoacetate 3a $(42 \%, 67 \%$ ee) and diol $\mathbf{2}(51 \%, 50 \%$ ee) and only $2 \%$ of diacetate $\mathbf{4 b}(99 \%$ ee). At $50^{\circ} \mathrm{C}(10 \mathrm{~W}, 14$ hours $)$ the same reaction yielded only esters: $58 \%$ of $(1 R, 2 R)$-monoacetate $3 \mathbf{a}$ with $55 \%$ ee and $37 \%$ of diacetate $\mathbf{4 b}$ ( $99 \%$ ee). A higher temperature $\left(80^{\circ} \mathrm{C}, 40 \mathrm{~W}, 14 \mathrm{~h}\right)$ afforded a decrease of diacetate yield with a lower enantiomeric excess (30\% of $\mathbf{4 b}$ with $93 \%$ ee).

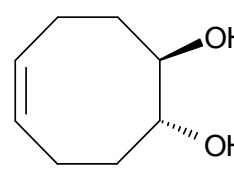

(1R,2R)

$2 \mathrm{a}$

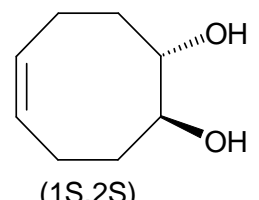

$(1 \mathrm{~S}, 2 \mathrm{~S})$

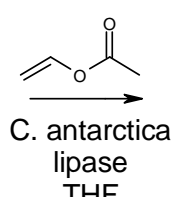

THF

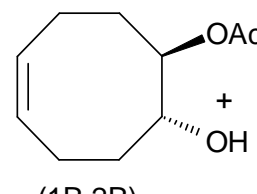

$(1 \mathrm{R}, 2 \mathrm{R})$

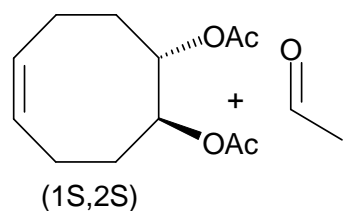

$4 b$

\begin{tabular}{cc|cc|cc}
\multicolumn{2}{c}{$2 \mathrm{~b}$} & \multicolumn{3}{c}{$3 \mathrm{a}$} & $4 \mathrm{~b}$ \\
\hline $\begin{array}{c}\text { Power } \\
(\mathbf{W})\end{array}$ & $\begin{array}{c}\text { Temperature } \\
\left({ }^{\circ} \mathbf{C}\right)\end{array}$ & $\begin{array}{c}\text { Monoacetate } \\
\text { yield (\%) }\end{array}$ & $\begin{array}{c}\text { 3a } \\
\text { ee (\%) }\end{array}$ & $\begin{array}{c}\text { Diacetate } \\
\text { Yield (\%) }\end{array}$ & $\begin{array}{c}\text { 4b (\%) } \\
\text { (\%) }\end{array}$ \\
\hline 5 & 35 & 32 & 45 & 5 & 99 \\
10 & 50 & 58 & 55 & 37 & 99 \\
20 & 80 & 55 & 57 & 30 & 94 \\
40 & 100 & - & - & - & - \\
300 & 35 & 42 & 67 & 2 & $>99$ \\
\hline
\end{tabular}

Table 2 : Enantioselective acetylation of diol (2) using CaLB lipase by microwave irradiation

These results suggest that at higher temperature $\left(80-100{ }^{\circ} \mathrm{C}\right)$, there is a loss of enzyme activity and selectivity due to its denaturation. The power of irradiation displays key role in enzyme properties: enhancement of monoacetate yield and ee being observed at $35^{\circ} \mathrm{C}$ with $300 \mathrm{~W}$.

At $50^{\circ} \mathrm{C}$ under conventional heating, enzyme-catalysed acylation of rac-diol 2 with PSD provide both $(1 S, 2 S)$-monoacetate $\mathbf{3 b}$ and $(1 R, 2 R)$-diol $\mathbf{2 a}$ in poor enantiomeric purity (respectively $45 \%$ ee for $\mathbf{3 b}$ and $3 \%$ ee for $\mathbf{2 a}$ ) and poor conversion $(6 \%)$. At higher temperature $\left(80,100^{\circ} \mathrm{C}\right)$ there is a loss of activity. Under microwave irradiation at $50^{\circ} \mathrm{C}(15 \mathrm{~W})$, lipase resolution of racemic diol 2 afforded $(1 \mathrm{~S}, 2 \mathrm{~S})$-monoacetate $3 \mathbf{b}(41 \%, 50 \%$ ee) and $(1 R, 2 R)$-diol $(57 \%, 35 \%$ ee). The microwave irradiation method gave a higher conversion value compared using conventional heating. At $80^{\circ} \mathrm{C}(35 \mathrm{~W})$, the reaction yielded $12 \%$ of $3 \mathbf{b}$ ( $35 \%$ ee) and $66 \%$ of diol with no selectivity (5\% ee). 


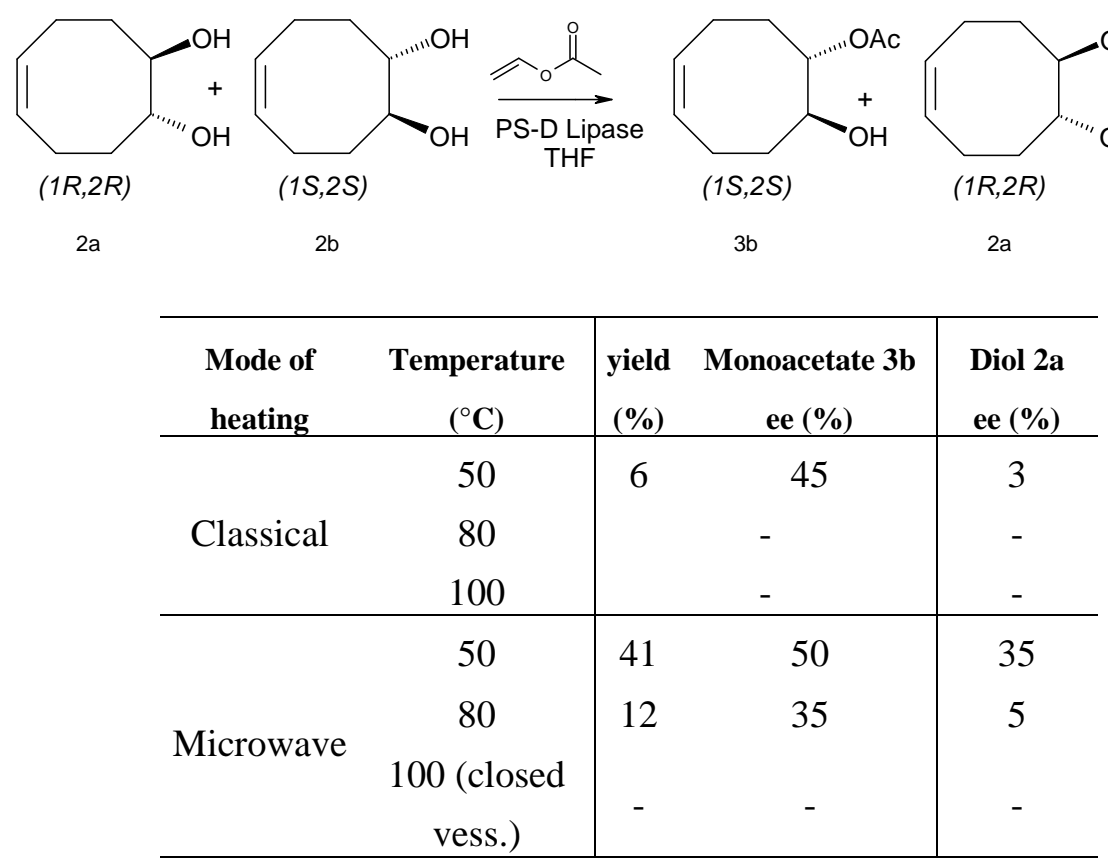

Table 3: Acetylation of diol (2) using immobilized PS lipase (PS-D)

Compared to CalB, PSD exhibited a reverse enantiopreference for the monoacetate $(1 S, 2 S)$.

Then, we investigated the enzymatic enantioselective hydrolysis from rac-diacetate $\mathbf{4}$ according to Suemune procedure. ${ }^{6}$ Instead of using PFL (Pseudomonas fluorescens lipase) as described by Suemune, we used immobilized CaLB and PSD in order to perform later the reaction under microwave. Performed at various temperature $\left(35,50\right.$ and $\left.80^{\circ} \mathrm{C}\right)$ under conventional heating CalBcatalyzed hydrolysis of rac-diacetate (4) in phosphate buffer $(0.1 \mathrm{M}, \mathrm{pH} 7.0)$ led only to traces of monoacetate at $50^{\circ} \mathrm{C}$. Compared to conventional heating, the microwave irradiation at $50^{\circ} \mathrm{C}$ during 14 hours led to a higher conversion (20\%) with excellent enantiomeric excesses for monoacetate (ee: $97 \%$ for $\mathbf{3 b}(1 S, 2 S))$ besides diacetate $\mathbf{4 a}($ ee: $34 \%)$.

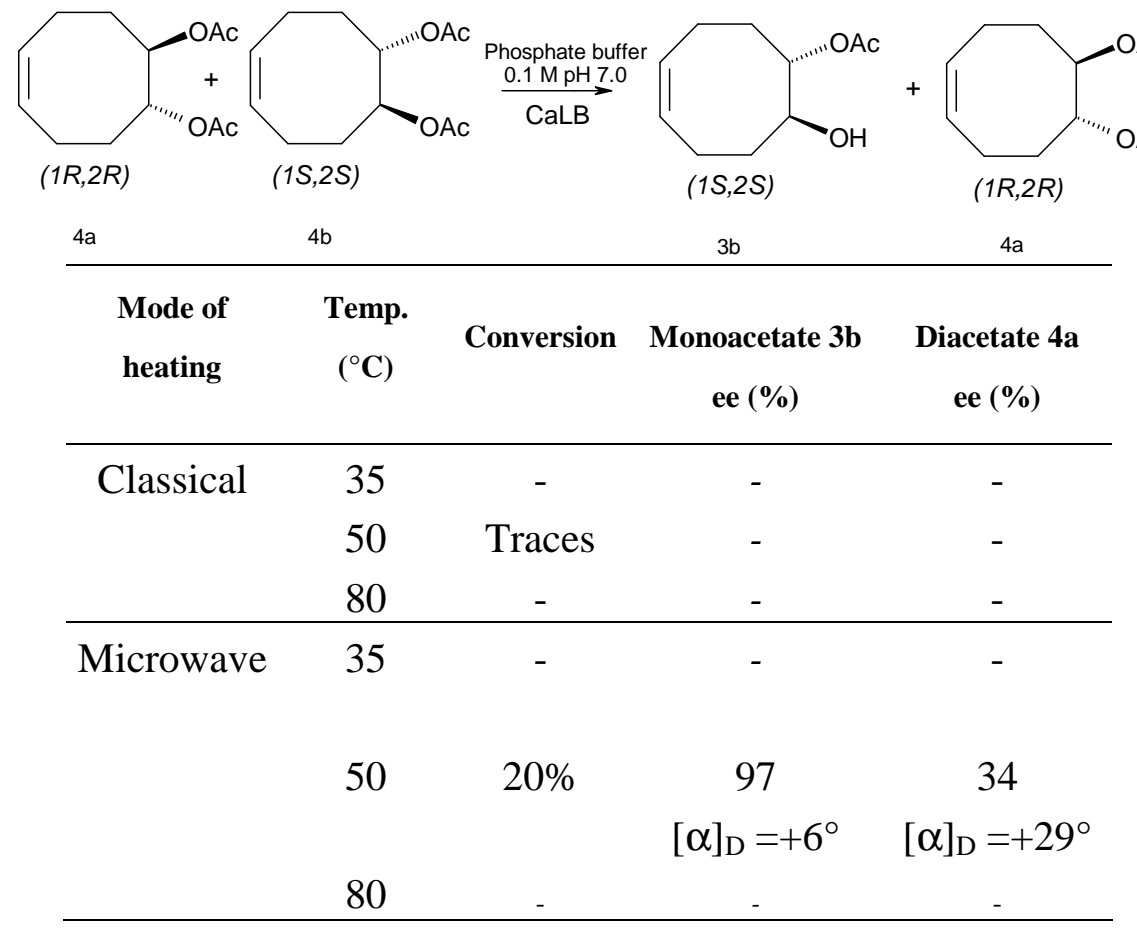

Table 4 : Hydrolysis of diacetate (4) using CaLB lipase 
The recovered $(1 R, 2 R)$-diacetate $\mathbf{4 a}$ of $34 \%$ ee was submitted twice to the same enzymatic hydrolysis under microwave irradiation $\left(2 \times 14 \mathrm{~h}, 50^{\circ} \mathrm{C}, 5 \mathrm{~W}\right)$. Pure $(1 R, 2 R)$-diacetate $4 \mathbf{a}$ was obtained in $49 \%$ yield from rac-4.

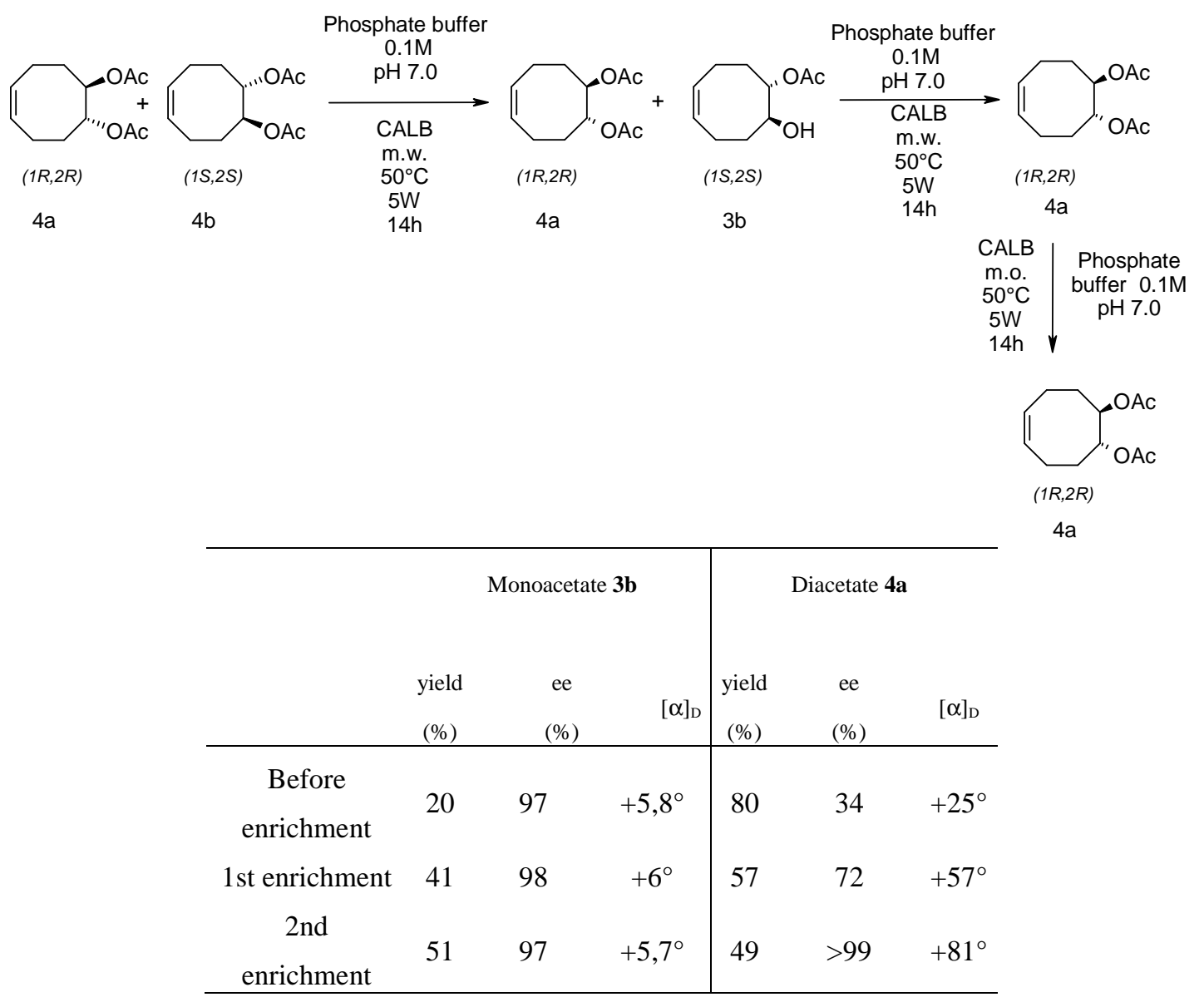

Table 5 : Enrichment of diacetate (4a) 
The hydrolysis using PS-D was conducted in the same manner. In classical conditions whatever the temperature $\left(35,50,80^{\circ} \mathrm{C}\right)$ and the reaction time (14h, 7 days), in no case conversion to monoacetate 3 was observed. Interestingly, under microwave irradiation at $50^{\circ} \mathrm{C}(14 \mathrm{~h})$, rac-diacetate 4 was resolved into (-)-( $(1 R, 2 R)$ monoacetate $3 \mathbf{a}$ with $81 \%$ ee and $(S, S)$-diacetate $\mathbf{4 b}(28 \%$ ee). This result highlights a non thermal effect.

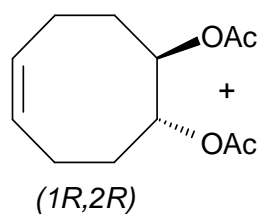

$4 a$

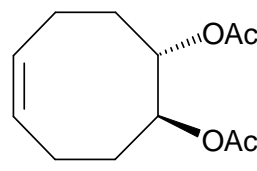

$(1 S, 2 S)$

Phosphate buffer $0.1 \mathrm{MpH} 7.0$ PS-D lipase

$4 b$

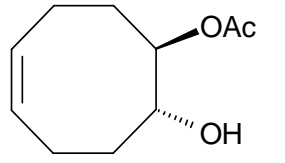

$(1 R, 2 R)$

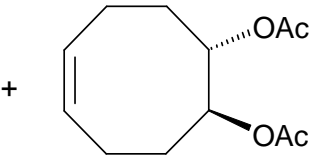

$(1 S, 2 S)$

3a $4 \mathrm{~b}$

\begin{tabular}{ccc|c|c}
\hline Mode of heating & Temp. $\left({ }^{\circ} \mathrm{C}\right)$ & Conversion & $\begin{array}{c}\text { Monoacetate 3a } \\
\text { ee (\%) }\end{array}$ & $\begin{array}{c}\text { Diacetate 4b } \\
\text { ee (\%) }\end{array}$ \\
\hline Classical & 35 & - & - & - \\
& 50 & - & - & - \\
Microwave & 80 & - & - & - \\
& 35 & - & - & - \\
& 50 & $10 \%$ & 81 & 28 \\
{$[\alpha]_{\mathrm{D}}=-4^{\circ}$} & - & - \\
{$[\alpha]_{\mathrm{D}}=-24^{\circ}$}
\end{tabular}

Table 6 : Hydrolysis of diacetate (4) using PS-D lipase

The obtained enantiopur monoacetates $\mathbf{3 a}, \mathbf{3 b}$ and diacetates $\mathbf{4 a}$ and $\mathbf{4 b}$ after enantio-enrichments were then quantitatively converted into $(1 R, 2 R)$-diol $\mathbf{2 a}$ and $(1 S, 2 S)$-diol $\mathbf{2} \mathbf{b}$ of $>99 \%$ ee by methanolysis. ${ }^{6}$<smiles>CC(=O)OC1CCC=CCCC1O</smiles>

$(1 \mathrm{R}, 2 \mathrm{R})$

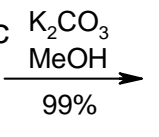

$[\alpha]_{D}^{20}=-20,9^{\circ}\left(\mathrm{C}=1.00 \mathrm{CHCl}_{3}\right)$<smiles>CC(=O)OC1CCC=CCCC1OC(C)=O</smiles>

$(1 \mathrm{~S}, 2 \mathrm{~S})$<smiles>OC1CCC=CCCC1O</smiles><smiles>OC1CCC=CCC[C@H]1O</smiles>

$(1 S, 2 S)$

$$
[\alpha]_{D}^{20}=+18.2^{\circ}\left(\mathrm{C}=1.00 \mathrm{CHCl}_{3}\right)
$$

\section{Conclusions}

The resolution of homochiral diol has been fulfilled in clean and rapid way using the microwaveassisted biocatalysis. The enantiopreference was guide using two lipases to obtain one or the other useful enantiomer. The role of the microwave power has also been highlighted. Finally, by microwave irradiation, this eco-efficient optimization for the resolution of racemic diols, leads to a reduction of the reaction time, a decrease of power consumption, without any toxicity

\section{Acknowledgments}


The authors would like to thank ANR EXPENANTIO, la "Ligue Nationale Contre le Cancer" for financial supports and the "Ministère de la Recherche et de l'Enseignement Supérieur" for PhD grant (HR).

\section{References and Notes}

1. Bornscheuer, U.T., Kazlauskas, R.J. Hydrolases in Organic synthesis 2nd Ed. WILEY-VCH, Verlag GmbH \& Co. KGaA, Weinheim, 2006. 99.

2. (a) G.F. Vincente, R. Brieva, V. Gotor, Journal of Molecular Catalysis B: Enzymatic, 2006, 40, 111. (b) Pchelka, B.; Loupy, A.; Petit, A. Tetrahedron : Asymmetry. 2006, 17, 2516. (c) Bachu, P.; Sperry, J.; Brimble, M. Tetrahedron. 2008, 64, 3343. (d) Leadbeater, N.; Stencel, L.; Wood, E. Organic and Biomolecular Chemistry. 2007, 5, 1052. (e) A. Parvulescu, P. Jacobs, D. De Vos, Applied Catalysis A: General, 2009, 368, 9. (f) Octavio, R., Souza, M.A., Antunes, O.A., Kroutil, W., Kappe, C.O. J. Org. Chem., 2009, 74, 6157. (g) G.D. Yadav, S. V. Pawar, Appl Microbiol Biotechnol.,2012, 96, 69.

3. H. Rouillard, J.R. Chérouvrier, V. Thiéry, Ultrasound and Microwave: Recent Advances in Organic Chemistry. Research Signpost, Chapter 6: Biocatalysis under microwave irradiation, 2011, 175. ISBN : 978-81-7895-532-2.

4. (a) Bódai, V.; Orovecz, O.; Szakács, G.; Novák, L.; Poppe, L. Tetrahedron: Asymmetry. 2003, 14, 2605. (b) Onomura, O.; Arimoto, H.; Matsumura, Y.; Demizu, Y. Tetrahedron Letters. 2007, 48, 8668. (c) Demizu, Y.; Matsumoto, K.; Onomura, O.; Matsumura, Y. Tetrahedron Letters. 2007, 48, 7605. (d) Wakita, N.; Hara, S. Tetrahedron. 2010, 66, 7939.

5. (a) Suemune, H.; Hizuka, M.; Kamashita, T.; Sakai K. Chemical and Pharmaceutical Bulletin. 1989, 37, 1379. (b) Suemune, H. ; Hasegawa A. ; Sakai, K. Tetrahedron: Asymmetry. 1995, 6, 55.

6. Horikawa, T.; Norimine, Y.; Tanaka, M.; Sakai, K.; Suemune, H. Chemical and Pharmaceutical Bulletin. 1998, 46, 17. 